\title{
AOR
}

Selected Papers of \#AolR2019:

The $20^{\text {th }}$ Annual Conference of the Association of Internet Researchers Brisbane, Australia / 2-5 October 2019

\section{"HEY, I LIKE YOUR VIDEOS. RELATE MUCH!"LOCATING SISTERHOOD IN A POSTCOLONIAL PUBLIC ON YOUTUBE}

\author{
Earvin Charles B. Cabalquinto \\ Deakin University, Australia \\ Cheryll Ruth Soriano \\ De La Salle University, Philippines
}

The advent of convergent online platforms revolutionised the ways in which migrants connect to diverse groups and in various contexts. Social media platforms have enabled migrants to curate and display their private lives online (Komito, 2011; Madianou \& Miller, 2012). Such online performances of everyday life forges a 'digital intimate public' (Dobson, Robards, \& Carah, 2018). Intimate connectivity and trust are facilitated through relatability (Kanai, 2019) and authenticity (Banet-Weiser, 2012), which are both structured by heteronormative systems (Duffy \& Hund, 2015). Paradoxically, social media use fosters both connectivity and communicative risks and abuse (Salter, 2018).

As part of a broader project that seeks to investigate the brokering of digitally-mediated intimacies through matchmaking platforms and social media channels, this paper unpacks the formation of 'online sisterhood' in a postcolonial intimate public, as evinced in the comments of viewers on selected YouTube videos of Rhaze, a Filipina YouTuber who is married to an Australian man. With a massive following of over 450 thousand followers, Rhaze's videos typically receive diverse comments from her viewers and subscribers. This exposition is facilitated by collecting, categorising and analysing selected comments from Rhaze's top videos. The comments were analysed through discourse analysis, paying special attention to the factors that influence digital media practices (Keightley \& Reading, 2014).

The findings reveal that competing comments are shaped by postcolonial views on a gendered, racialized and class-based body in an interracial relationship. One type of Suggested Citation (APA): Cabalquinto E.C. and Soriano, C. R. (2019, October 2-5). "Hey, I like your videos. Relate much!" Locating sisterhood in a postcolonial public on YouTube. Paper presented at AolR 2019: The $20^{\text {th }}$ Annual Conference of the Association of Internet Researchers. Brisbane, Australia: AolR. Retrieved from http://spir.aoir.org. 
comment applauds Rhaze for being bold in using a dating website, taking risks by meeting the man overseas, and eventually marrying him. A sense of authenticity on YouTube is attained (Raun, 2018) through 'bold confessions'. Further, viewers find Rhaze's experiences as relatable. This is most salient whenever she performs the role of a nurturing partner of a foreigner. We argue then that the appeal of Rhaze's performances, implicitly or explicitly, feeds the imaginaries of the viewers of a prescribed femininity in a neoliberal and postcolonial state -- a caring partner, a filial family member or a good citizen of the Philippines. Personalised videos articulate ideological messages about what a Filipino woman is and can be. In examining an intimate connectivity between Rhaze and her viewers, we coin the term 'online sisterhood'. Such proposition builds on the proposed term 'local sisterhood' by Roces (2003), emphasising how Filipino women married to Australian men in remote towns find support and comfort by forging friendship with fellow Filipinas married to a foreign national. Such modality, we argue, surfaces in online spaces wherein women gravitate to each other based on trust and mutual understanding of lived conditions.

However, derogatory comments can also emerge in an online space. Terms such as 'gold-digger' or 'don't be hypocrite' are used by other 'bashers' on YouTube. This goes to show how discrimination of a Filipina spreads across physical spaces (Aquino, 2018) and the space of mainstream media (Espinosa, 2017; Laforteza, 2006) and online channels. We argue that discriminating comments are linked to pre-existing prejudices toward Filipino women who marry white foreign nationals through matchmaking websites. Often, the image of a Filipina in an interracial relationship is branded as 'mailorder bride'. Historically, women from poor socio-economic background are purchased by white men through mail-order websites (Constable, 2003; Tolentino, 1996). Generalised and stereotypical views are then reflected in the comments of some individuals on YouTube. Significantly, online sisterhood becomes a collective strategy in dismissing belittling comments. For instance, other commenters defend Rhaze's persona and positionality in an interracial relationship.

This paper emphasises that sisterhood reflects the shared support that women nurture with other women through online practices. However, we argue that such cohesion, if performed as detached from the broader context of feminised migration, may reinforce systems that marginalise women. Online performances and comments only generate positive affects that may perpetuate neo-colonial and neoliberal subjectivity. Digital practices may eclipse the historical and political context of transnational mobility of women in a globalised economy. For instance, women, who do not have access to work opportunities, often capitalise on their skills and bodies to secure a future for themselves and their loved ones (Parreñas, 2011). A neoliberal state amplifies feminised migration by constructing women as self-sacrificing and entrepreneurial individual (Guevarra, 2010; Rodriguez, 2010). Ultimately, online sisterhood in a postcolonial intimate public displays how Filipino women generate and negotiate spaces of mutual support in a neoliberal state. Paradoxically, a neoliberal government benefits from such cross-border and mediated mobility of Filipina migrants through the commodification of their everyday life. It is through this point that we argue for a closer 
evaluation of the role of 'online sisterhood' in the construction of female subjectivity and imaginaries of mobility in the Global South.

\section{References}

Aquino, K. (2018). Racism and resistance among the Filipino diaspora: Everyday antiracism in Australia (Vol. Routledge): London.

Banet-Weiser, S. (2012). Authentic TM: The politics and ambivalence in a brand culture: New York, NY : New York University Press, [2012].

Constable, N. a. (2003). Romance on a global stage: Pen pals, virtual ethnography, and "mail-order" marriages. Berkeley: University of California Press.

Dobson, A. S., Robards, B., \& Carah, N. (2018). Digital intimate publics and social media: Towards theorising public lives on private platforms. In A. S. Dobson, B. Robards, \& N. Carah (Eds.), Digital Intimate Publics and Social Media (pp. 3 27). Switzerland: Palgrave Macmillan.

Duffy, B. E., \& Hund, E. (2015). "Having it all" on Social Media: Entrepreneurial femininity and self-branding among fashion bloggers. Social Media + Society, 1(2), $1-11$

Espinosa, S. A. a. (2017). Sexualised citizenship: A cultural history of PhilippinesAustralian migration. Gateway East, Singapore: Palgrave MacMillan.

Guevarra, A. R. (2010). Marketing dreams, manufacturing heroes: The transnational labor brokering of Filipino workers. New Brunswick: Rutgers University Press.

Kanai, A. (2019). Gender and Relatability in Digital Culture: Managing Affect, Intimacy and Value. Basingtoke: Palgrave Macmillan.

Keightley, E., \& Reading, A. (2014). Mediated mobilities. Media, Culture \& Society, 36(3), 285-301. doi:10.1177/0163443713517731

Komito, L. (2011). Social media and migration: virtual community 2.0. Journal of the American Society for Information Science and Technology, 62(6), 1075-1086.

Laforteza, E. (2006). What a drag! Filipina/white Australian relations in the Adventures of Priscilla Queen of the dessert. ACRAWSA e-journal, 2(2), 1-18. 
Madianou, M., \& Miller, D. (2012). Migration and new media: Transnational families and polymedia. Abingdon, Oxon: Routledge.

Parreñas, R. S. (2011). Illicit Flirtations: Labor, Migration and Sex Trafficking in Tokyo Standford: Standford University Press.

Raun, T. (2018). Capitalizing Intimacy: New subcultural forms of micro-celebrity strategies and affective labour on YouTube. Convergence, 24(1), 99 - 113.

Roces, M. (2003). Sisterhood is Local: Filipino Women in Mount Isa. In N. Piper \& M. Roces (Eds.), Wife or worker? : Asian women and migration (pp. 71 - 100). Lanham, MD: Rowman \& Littlefield.

Rodriguez, R. M. (2010). Migrants for export: How the Philippine state brokers to the world. Minneapolis: The University of Minnesota Press.

Salter, M. (2018). Publicising Privacy, Weaponising Publicity: The dialectic of online abuse on social media. In A. S. Dobson, B. Robards, \& N. Carah (Eds.), Digital Intimate Publics and Social Media (pp. 29 - 44). Switzerland: Palgrave Macmillan.

Tolentino, R. B. (1996). Bodies, Letters, Catalogs: Filipinas in Transnational Space. Social Text(48), 49-76. doi:10.2307/466786 